University of Michigan Law School University of Michigan Law School Scholarship Repository

Articles

Faculty Scholarship

2013

\title{
Income and Substitution Effects of Estate Taxation
}

James R. Hines Jr.

University of Michigan Law School, jrhines@umich.edu

Available at: https://repository.law.umich.edu/articles/1022

Follow this and additional works at: https://repository.law.umich.edu/articles

Part of the Law and Economics Commons, and the Taxation-Federal Estate and Gift Commons

\section{Recommended Citation}

Hines, James R., Jr. "Income and Substitution Effects of Estate Taxation." Am. Econ. Rev. 103, no. 3 (2013): 484-8.

This Article is brought to you for free and open access by the Faculty Scholarship at University of Michigan Law School Scholarship Repository. It has been accepted for inclusion in Articles by an authorized administrator of University of Michigan Law School Scholarship Repository. For more information, please contact mlaw.repository@umich.edu. 


\title{
Income and Substitution Effects of Estate Taxation
}

\author{
By JAMES R. HINES, JR.*
}

Despite the long US history of taxing estates, the economic consequences of estate taxation in practice remain unclear. The US estate tax first appeared in 1797, only to be repealed in 1802. Estate taxes were subsequently imposed on a temporary basis from 1862-1872 and 1898-1902 to finance wartime expenditures. The modern estate tax was introduced in 1916, and, with varying exemption levels and tax rates, including a hiatus during 2010, has remained in force ever since. Taxes generally have been imposed only on large estates, the current $\$ 5.25$ million exempt amount implying that smaller estates escape federal taxes altogether.

The estate tax serves two functions: it collects revenue from large estates, and it discourages the transmission of wealth at death. It is an understatement to say that the US estate tax is controversial (for more of an explicit statement and historical elaboration see Graetz and Shapiro 2005), as there is controversy over both the desirability of imposing estate tax burdens and the economic consequences of incentives created by estate taxation. One of the sources of differences in views over the likely effects of estate taxation is differing degrees of rationality and foresight that are attributed to economic actors.

The purpose of this paper is to analyze incentives created by estate taxes in a setting in which agents act rationally and are endowed with accurate foresight. Since estate taxes reduce resources available to individuals, and also affect relative prices, the taxes have income and substitution effects on labor supply, consumption, saving, and other economic decisions. The paper considers the net impact of these effects

* Department of Economics, University of Michigan, 343 Lorch Hall, 611 Tappan Street, Ann Arbor, MI 48109 (e-mail: jrhines@umich.edu). I thank Jon Bakija, Charles Brown, and Wojciech Kopczuk for helpful comments on an earlier draft of this paper.

$\dagger$ To view additional materials, and author disclosure statement(s), visit the article page at http://dx.doi.org/10.1257/aer.103.3.484. on labor supply, which has been the focus of much of the empirical estate tax literature (e.g., Holtz-Eakin, Joulfaian, and Rosen 1993; Joulfaian and Wilhelm 1994; and Brown, Coile, and Weisbenner 2010), and which affords an opportunity to identify the income and substitution considerations that affect other economic variables such as consumption and saving. The analysis does not presume that actual estate taxes are optimal, and indeed, the realities of the political process that determines estate tax rates and exemption levels makes many observers question whether the practice of US estate taxation bears much relationship to optimal taxation.

An important consideration in evaluating income and substitution effects is whether or not bequests are purposeful. Wealthy individuals can spend their money or give it away to others, including gifts in the form of bequests that require retaining assets until death. Rational individuals are of course aware of their own mortality, but may nevertheless make accidental bequests if they die unexpectedly and in possession of bequeathable assets that had been intended for other purposes. There is a sizable literature (e.g., Kopczuk 2003; Kopczuk and Lupton 2007) that considers the determinants of bequests and the implications of accidental bequests for optimal estate taxation. This paper instead evaluates the effects of estate taxation, whether optimal or not, in a setting in which individuals can reasonably anticipate, and plan for, their own deaths. Such planning may include annuitizing a considerable portion of lifetime resources and setting aside the remainder for bequests (Sheshinski 2008).

A second important consideration is whether bequests are gratuitous. The alternative is that bequests are a form of payment (Bernheim, Shleifer, and Summers 1985), say for services rendered by subsequent legatees (those to whom bequests are directed). Bequests that are forms of payment do not contribute to the well-being of legatees to the same extent as do gratuitous bequests, since in the latter case legatees need 
not offer something in return. The model follows much of the literature in assuming that bequests are gratuitous, returning in the conclusion to some of its implications.

If bequests are purposeful and gratuitous then estate taxes have two separate income effects on labor supply. The first is that estate taxes affect the magnitudes of after-tax receipts, both by reducing the amount of any pretax estate ultimately received by legatees, and by possibly affecting pretax bequests. The second income effect arises because estate taxes reduce the wellbeing of those who plan to make bequests. Estate taxes raise the cost of transmitting resources to legatees, and thereby reduce the real net worth of those with property intended for transmission at death. The combination of these two income effects reflects that if bequests are gratuitous and intentional, then their taxation imposes burdens not only on those who receive but also on those who give-including, commonly, the same individuals, who receive at one stage of life and give at another.

In addition to their income effects, estate taxes have substitution effects on labor supply. Estate taxes increase the cost of bequeathing after-tax resources relative to the costs of leisure and present consumption. If leisure and bequests are substitutes, which is likely, then the substitution effect of higher estate taxes is to discourage labor supply. Since the two income effects will generally encourage labor supply, whereas the substitution effect generally discourages it, the net impact of estate taxes on labor supply depends on relative magnitudes. Empirical labor supply elasticity estimates suggest that, despite two income effects pushing in the direction of making higher estate taxes encourage labor supply, the effect of the estate tax on aggregate labor supply is of uncertain sign.

\section{Decomposing Income and Substitution}

In a model in which individuals live for one period, individual utility can be expressed as a function of exogenous income, government resources, and relative prices. Utility can be written in indirect form as $V(y, g, w, p)$, in which $y$ is exogenous resources, $g$ is government tax revenue, $w$ is the after-tax wage, and $p$ is the price of bequeathing an additional after-tax dollar to legatees. The price of current consumption is normalized to unity. The assumption that individuals choose their bequests requires the inclusion of the price of bequests as an argument of the utility function. Exogenous resources include any after-tax bequests received from others.

For convenience the estate tax is taken to be a linear function of bequests above an exempt amount, and the analysis considers only bequests above this amount. If bequests are subject to tax at rate $t$, then the price of after-tax bequests for a taxable estate is $1 /(1-t)$. Letting $B$ denote pre-tax bequests that an individual chooses to leave, and $E$ the exempt amount, it follows that $B(1-t)+E t$ is after-tax bequests, and the government collects tax revenue of $(B-E) t$ from an individual's bequests. Taking the same tax parameters to apply to receipts, and using an asterisk to denote receipts, an individual receives $B^{*}(1-t)+E t$ in after-tax bequests from the previous generation.

An individual's labor supply is likewise a function of exogenous income, government revenue, and prices, and therefore can be denoted $L(y, g, w, p)$. The effect of a permanent change in the tax rate has an obvious decomposition as

(1) $\frac{d L}{d t}=\frac{\partial L}{\partial y} \frac{d y}{d t}+\frac{\partial L}{\partial g} \frac{d g}{d t}+\frac{\partial L}{\partial p} \frac{d p}{d t}$.

In evaluating (1), $d p / d t=1 /(1-t)^{2}$, and the effect of the tax change on tax revenue (if labor income is untaxed) is $d g / d t$ $=t d B^{*} / d t+B^{*}-E$. The effect of the tax change on exogenous after-tax bequest receipt is $\quad d y / d t=(1-t) d B^{*} / d t-B^{*}+E$. Furthermore, the derivative of labor supply with respect to the price change can be decomposed into a substitution effect and an income effect: $\frac{\partial L}{\partial p}=\frac{\partial L^{c}}{\partial p}-\frac{\partial L}{\partial y}(B-E)(1-t)$, in which $\frac{\partial L^{c}}{\partial p}$ is the compensated effect of a price change on labor supply.

If government tax revenue enters the utility function in an additively separable fashion, then $\frac{\partial L}{\partial g}=0$, and (1) implies

$$
\begin{aligned}
& d L / d t=\frac{\partial L^{c}}{\partial p} \frac{1}{(1-t)^{2}} \\
& +\frac{\partial L}{\partial y}\left[(1-t) \frac{d B^{*}}{d t}-\left(B^{*}-E\right)-\frac{(B-E)}{(1-t)}\right] .
\end{aligned}
$$

The first term on the right side of equation (2) is the substitution effect of estate taxation on 
labor supply, whereas the second term is the income effect. The substitution effect is rather straightforward, but the income term reflects the two components of income that are affected by estate tax changes, and that arise because individuals receive as well as leave estates.

The terms including variables with asterisks on the right side of (2) reflect the effect of a tax change on the after-tax portion of bequests that is taxable; their sum equals the value of the derivative $d\left[\left(B^{*}-E\right)(1-t)\right] / d t$. If this derivative equals zero, then estate tax changes slightly increase net receipts of legatees (by increasing the value of the exempt amount), as pretax bequests increase in response to the tax changes. Since such an outcome would require lifetime consumption of those who leave bequests to fall dramatically in response to estate tax changes, it is much more likely that the derivative is negative; for example, if bequest behavior is unresponsive to tax changes, $d\left[\left(B^{*}-E\right)\right.$ $(1-t)] / d t=-\left(B^{*}-E\right)$.

In order to consolidate terms it is helpful to consider a steady state in which bequests are unchanging across generations. Since such a steady state has the property that $B=B^{*}$, it is then possible to define an elasticity of after-tax portion of taxable bequests with respect to one minus the tax rate. Denoting $\varepsilon \equiv[1 /(B-E)]$ $\times d[(B-E)(1-t)] / d(1-t)$, it follows that

(2) can be rewritten as

$$
\begin{aligned}
d L / d t= & \frac{\partial L^{c}}{\partial p} \frac{1}{(1-t)^{2}} \\
& -\frac{\partial L}{\partial y} \frac{(B-E)}{(1-t)}(1+\varepsilon) .
\end{aligned}
$$

The decomposition in equation (3) has the look of a standard separation of substitution effects of price changes, but for the $(1+\varepsilon)$ term on the right side. If individuals make bequests but do not receive them, then $\varepsilon=0$. If individuals receive bequests, and pretax bequests are for some reason unaffected by estate taxation, then $\varepsilon=1$, thereby doubling the income effect compared to a setting in which there is a tax-induced price change without gratuitous transfers. More generally, the presence of the elasticity term on the right side of equation (3) picks up the second income effect of estate tax changes on labor supply.

\section{Empirical Implications}

In order to evaluate the likely effects of estate taxation on labor supply it is helpful to recast equation (3) in a manner that expresses empirical magnitudes as commonly estimated elasticities. Denoting the Marshallian own-price labor supply elasticity as $M \equiv \frac{\partial L}{\partial w} \frac{w}{L}$, and the Hicksian own-price labor supply elasticity as $H \equiv \frac{\partial L^{c}}{\partial w} \frac{w}{L}$, it follows from the Slutsky equation that $\frac{\partial L}{\partial y}=\frac{(M-H)}{w}$. Properties of compensated demands guarantee that $H>0$, and while the sign of $M$ depends on the relative importance of substitution and income effects, it is common to assume (though by no means universal to estimate) that $M>0$.

The magnitude of the substitution effect depends on the extent to which leisure and bequests are Hicksian substitutes or complements. Both are possibilities, since a third good, present consumption, also affects utility. Much of the literature makes the simplifying assumption that utility is weakly separable in leisure and in a composite of present consumption and after-tax bequests, which carries the implication that both bequests and present consumption are Hicksian substitutes for leisure. This weak separability assumption also implies that the substitution effect of estate taxes on labor supply stem solely from the fact that higher estate taxes increase the cost of the consumption bundle purchased with greater labor effort. Specifically, the separability assumption implies that $\frac{\partial L^{c}}{\partial p}=-\frac{\partial L^{c}}{\partial w} \frac{B(1-t)}{L}$. Applying the Hicksian definition, it follows that $\frac{\partial L^{c}}{\partial p}=-H \frac{B(1-t)}{w}$.

A final notational convenience is to define $\alpha \equiv E / B$ as the ratio of the estate tax exemption to the size of the equilibrium pretax estate. Together, these simplifications imply that equation (3) can be expressed as

$w \frac{d L}{d t}=\frac{-B}{(1-t)}[H+(M-H)(1-\alpha)(1+\varepsilon)]$.

The left side of equation (4) is the change in labor earnings occasioned by a change in the estate tax rate. The first term in brackets on the right side reflects substitution and is clearly negative. The second term in brackets on the 
right side of (4) is the income effect, and is therefore a function of the difference between the Hicksian and Marshallian labor supply elasticities. Clearly, if $(1-\alpha)(1+\varepsilon)=1$ then equation (4) implies that $w \frac{d L}{d t}=\frac{-B M}{(1-t)}$, and greater estate taxes discourage labor supply if the Marshallian labor supply schedule is upward-sloping. More generally, however, one should expect $(1-\alpha)(1+\varepsilon)$ to exceed unity, reflecting the negative impact of estate taxes on receipts of after-tax bequests.

A higher value of $\alpha$ corresponds to a greater estate tax exemption relative to equilibrium bequests, which dampens the income effect of estate taxation while leaving its substitution effect unchanged. The value of $\alpha$ depends in part on legislative choice of how large to make the estate tax exemption, and this has changed considerably over the years. The IRS Statistics of Income (http://www.irs.gov/uac/Tax-Stats-2) reports that, among estate tax returns filed in 2009 , the available unified credit reduced the $\$ 33.8$ billion tentative estate tax liability of taxable returns by $\$ 11.8$ billion, or 35 percent of its value. In the model this corresponds to a value of $\alpha=0.35$.

How large is $\varepsilon$ ? As noted earlier, if pretax bequests do not respond to estate taxation, then $\varepsilon=1$; whereas if pretax bequests decline at higher tax rates, then $\varepsilon>1$. Very little is known about the effect of estate taxes on pretax bequests (Kopczuk forthcoming surveys the limited available literature), so the range of plausible potential values of $(1-\alpha)(1+\varepsilon)$ is perhaps rather wide, though a high value in that range might be two. If $(1-\alpha)(1+\varepsilon)=2$, then equation (4) becomes

$$
w \frac{d L}{d t}=\frac{B}{(1-t)}(H-2 M)
$$

If the Marshallian labor supply elasticity is negative, then the right side of equation (5) is positive, and higher estate taxes encourage greater labor supply. More commonly, the Marshallian labor supply elasticity is estimated to be positive, in which case the sign of the effect of estate taxation on labor supply then depends on the relative magnitudes of the Hicksian and Marshallian elasticities. Specifically, the sign depends on whether or not the Hicksian elasticity has double the magnitude of the Marshallian elasticity.
Keane (2011) offers a very useful critical survey of estimated labor supply elasticities. The studies reporting these estimates analyze data that cover different populations and time periods, and the resulting estimates differ as well due to methodological differences. Given the varying data populations and degrees of persuasiveness of the methods used, it is altogether too crude simply to aggregate these estimates. It is nonetheless interesting to note that, among the 21 surveyed studies of male labor supply for which Marshallian and Hicksian elasticity estimates are available, seven report negative Marshallian elasticities, corresponding to backward-bending labor supply functions. Among the remaining 14 studies, half report Hicksian elasticities that are more than double the magnitude of Marshallian elasticities, and half report Hicksian elasticities that are less than double the corresponding Marshallian elasticity. The Keane (2011) paper also surveys estimated female labor supply elasticities, though only two studies report both Hicksian and Marshallian elasticities; in one case, the estimated Marshallian elasticity is negative, whereas in the other (Blundell, Duncan, and Meghir 1998) the Marshallian elasticity is positive and only slightly smaller than the Hicksian.

What conclusion is appropriate to draw from this evidence? It would be fair to say that it is difficult to know either the sign or the magnitude of the effect of estate taxation on labor supply. One difficulty is that Marshallian and Hicksian labor supply elasticities estimated on large populations may not characterize the behavior of the part of the population that is affected by estate taxation. Even putting that consideration aside, and taking affluent families to exhibit labor market behavior that is similar to that of the population as a whole, the range of available estimates is too wide to afford much comfort in trying to summarize their implications for the magnitudes implied by equation (5). It is interesting to note the frequency with which available estimates imply that labor supply either rises or falls with higher estate tax rates, but even the substantial uncertainty over the sign of the response does not guarantee that its magnitude is small.

\section{Conclusion}

The estate tax discourages labor supply by reducing the return to work, but encourages labor supply by imposing burdens on individuals both as recipients of after-tax bequests and as 
those who plan to leave bequests. If labor supply responds to income changes, then this double burden of estate taxation has the potential to encourage labor supply more than the taxinduced relative price change discourages labor supply. Resolving the implication of the substitution and (double) income effects of the estate tax is an empirical matter, for which there is no consensus on the magnitudes of these effects for the population affected by the estate tax, or for that matter the population as a whole.

The double burden of the estate tax is characteristic of taxes on gratuitous transfers, and is the basis of Kaplow's (1995) conclusion that efficiency requires that gifts and estates be subsidized. These efficient subsidies need not be uniform; Farhi and Werning (2010) analyze the properties of welfare-maximizing income and estate taxes, concluding that the efficient estate tax subsidy rate declines with income. While the notion of subsidizing estates and other gratuitous transfers is inconsistent with observed tax policies and indeed runs contrary to the common practice of taxing gifts and estates, it is a natural implication of models in which those who make transfers fail to internalize all of the benefits of their gifts, and therefore in the absence of subsidies give inefficiently too little.

From the standpoint of a government with multiple tax instruments at its disposal, any effect of estate taxes on aggregate labor supply can in principle be reversed by adept use of other tax instruments. Estate taxes that are components of efficient tax profiles combining income and estate taxes may, depending on the structure of preferences and the available tax instruments, depend little or not at all on their effects on labor supply. It is nevertheless valuable to understand the likely implications of actual estate taxes for labor supply and other economic variables, and in particular to consider the ways in which double burdens of these taxes may influence economic outcomes.

\section{REFERENCES}

Bernheim, B. Douglas, Andrei Shleifer, and Lawrence H. Summers. 1985. "The Strategic
Bequest Motive." Journal of Political Economy 93 (6): 1045-76.

- Blundell, Richard, Alan Duncan, and Costas Meghir. 1998. "Estimating Labor Supply Responses Using Tax Reforms." Econometrica 66 (4): 827-61.

- Brown, Jeffrey R., Courtney C. Coile, and Scott J. Weisbenner. 2010. "The Effect of Inheritance Receipt on Retirement." Review of Economics and Statistics 92 (2): 425-34.

- Farhi, Emmanuel, and Ivan Werning. 2010. "Progressive Estate Taxation." Quarterly Journal of Economics 125 (2): 635-73.

Graetz, Michael J., and Ian Shapiro. 2005. Death by a Thousand Cuts: The Fight over Taxing Inherited Wealth. Princeton: Princeton University Press.

Holtz-Eakin, Douglas, David Joulfaian, and Harvey S. Rosen. 1993. "The Carnegie Conjecture: Some Empirical Evidence." Quarterly Journal of Economics 108 (2): 413-35.

- Joulfaian, David, and Mark O. Wilhelm. 1994. "Inheritance and Labor Supply." Journal of Human Resources 29 (4): 1205-34.

-Kaplow, Louis. 1995. "A Note on Subsidizing Gifts." Journal of Public Economics 58 (3): 469-77.

-Keane, Michael P. 2011. "Labor Supply and Taxes: A Survey." Journal of Economic Literature 49 (4): 961-1075.

-Kopczuk, Wojciech. 2003. "The Trick Is to Live: Is the Estate Tax Social Security for the Rich?" Journal of Political Economy 111 (6): 1318-41.

Kopczuk, Wojciech. Forthcoming. "Taxation of Intergenerational Transfers and Wealth." Handbook of Public Economics, Vol. 5, edited by Alan J. Auerbach, Raj Chetty, Martin Feldstein, and Emmanuel Saez. Amsterdam: North-Holland.

-Kopczuk, Wojciech, and Joseph P. Lupton. 2007. "To Leave or Not to Leave: The Distribution of Bequest Motives." Review of Economic Studies 74 (1): 207-35.

Sheshinski, Eytan. 2008. The Economic Theory of Annuities. Princeton: Princeton University Press. 